Nata Joksimović ${ }^{1}$ Jasmina Ćirić, Biljana Nedeljković Beleslin, Mirjana Stojković, Miloš Stojanović, Marija Miletić, Miloš Žarković

\title{
PARANEOPLASTIČNA HIPOGLIKEMIJA KOD PACIJENTA SA RECIDIVOM FIBROZNOG TUMORA PLEURE
}

Apstrakt: UVOD: Solitarni fibrozni tumor pleure je najčešći mezenhimalni tumor koji putem ektopične sekrecije IGF2 uzrokuje non-islet cell hipoglikemiju, nazvanu Doege Potterov sindrom.

PRIKAZ SLUČAJA: Muškarac, star 86 godina, primljen je na naše odeljenje zbog višemesečnih povremenih simptoma hipoglikemije i dve krize svesti kada su dokumentovane vrednosti šećera od 1.9 i $1.2 \mathrm{mmol} / \mathrm{L}$. Pacijent nije bolovao od dijabetesa. Pre dvadeset godina je operisan zbog primarnog pleuralnog fibroma koji je u potpunosti uklonjen. Šest meseci pred prijem učinjen je CT grudnog koša zbog respiratorne infekcije, i tada je vizuelizovan tumor veličine $103 \mathrm{~mm}$ u desnom režnju pluća. Tokom hospitalizacije je isključen hipokorticizam, hipopituitarizam i hipotireoza. Tokom spontanih epizoda neuroglikopenije više puta je verifikovana hipoinsulinemijska hipoglikemija. U hipoglikemiji su suprimovani nivoi hormona rasta i IGF1, povišen odnos IGF2 : IGF1 od 7:1. Nađene vrednosti hormona i rezultati glukagonskog testa govore u prilog paraneoplastične hipoglikemije u sklopu solitarnog fibroznog tumora pluća. Beta-hidroksibutirat nije određen zbog tehničkih nedostataka. Na MRI abdomena su opisane dobro ograničene ciste jetre i hemangiom. Oktreoskenom se nalazi umereno pojačano vezivanje u desnom hemitoraksu. Na kortikosteroidnoj terapiji, inicijalno zbog bronhoopstrukcije, dolazi do redukcije hipoglikemijskih epizoda. Pacijent je odbio operativno lečenje i otpušten je na adekvatnoj glukokortikoidnoj terapiji.

ZAKLJUČAK: Prikazan je slučaj retkog Doege Potterovog sindroma kod pacijenta koji ima recidiv solitarnog fibroznog tumora pleure i kod koga se detektuju suprimovane vrednosti hormona rasta i IGF1, uz povišen odnos IGF2 : IGF1. 
BACKGROUND: Solitary fibrous tumor of pleura represents a prototypical mesenchymal neoplasm that induces non-islet cell tumor hypoglycemia due to overproduction of insulin-like growth factor 2, named Doege Potter syndrome.

CASE PRESENTATION: An 86-year-old man, non-diabetic, was admitted to hospital with a few months history of repetitive hypoglycemic symptoms and documented low blood glucose of 1.9 and $1.2 \mathrm{mmol} / \mathrm{L}$ on two occasions when he lost consciousness. His medical history was notable for primary pleural fibroma which was resected twenty years previously and for tumorous mass of right pulmonal lobe $103 \mathrm{~mm}$ described on CT chest scan for respiratory infection six months prior to hospitalization. During hospitalization hypocorticism and hypoptuitarism were ruled out. He spontaneously developed mild neuroglycopenic episodes, when we confirmed hypoinsulinemic hypoglycemia accompanied with suppressed levels of growth hormone and IGF1, and IGF2 : IGF1 ratio of 7, which was all suggestive of paraneoplastic etiology. The response of glucose in Glucagon test was adequate. Beta-hydroxybutyrate was not done due to technical limitations. Abdominal MRI showed a few well-circumscribed cysts in the liver and hemangioma. Octreoscan revealed zone of diffuse increased uptake in right hemithorax. Subsequently, he was started on prednisolon for COPD exacerbation with which his hypoglycemic episodes subsided. Patient declined surgery and he was released with corticosteroid therapy.

CONCLUSIONS: We report a case of hypoinsulinemic hypoglycemia in a patient with suppressed levels of hGH and IGF1 and higher-than-normal IGF2 : IGF1 ratio, along with recurrent pleural tumor which is somatostatine-receptor positive.

\section{Uvod}

Epizode hipoglikemije se uglavnom javljaju kod pacijenata obolelih od dijabetesa, dok su nedijabetesne hipoglikemije znatno ređe i zahtevaju detaljno ispitivanje. Tipična klinička prezentacija podrazumeva tzv. Viplovu trijadu - serumsku glikemiju nižu od $2.5 \mathrm{mmol} / \mathrm{L}$ uz simptome neuroglikopenije koji se povlače sa davanjem glukoze ili obroka. Adrenergička simptomatologija može biti blaga ili odsutna. Nedijabetesne hipoglikemije mogu biti netumorske i tumorske. Među netumorskim hipoglikemijama su najčešće one izazvane lekovima, a drugi potencijalni uzroci su insuficijentna sekrecija kontraregulatornih hormona (kortizol, hormon rasta, adrenergički hormoni), teška oboljenja sa insuficijencijom mehanizama zaduženih za metaboličku homeostazu (sepsa, srčana insuficijencija i insuficijencija jetre, teške hemolize, poremećaji metabolizma glikogena, itd.), stanja nakon pojedinih operacija (adrenalektomija zbog feohromoci- 
toma, barijatrijska hirurgija kod morbidne gojaznosti, itd). Poseban entitet predstavlja insulin-autoimuni sindrom. (1) U osnovi tumorske hipoglikemije može biti insulinom, nezidioblastoza ili ektopična sekrecija "non-islet cell" tumora. Prvi opis hipoglikemije usled non-islet cell tumora (NICH) objavljen je 1930. godine. Brojni tumori su dovedeni u vezu sa paraneoplastičnom hipoglikemijom, a najčešće je reč o tumorima mezenhimskog porekla. U osnovi paraneoplastičnog sindroma stoji tumorska produkcija insulin-sličnih molekula koji se vezuju za insulinske receptore i istovremeno suprimuju endogenu insulinsku sekreciju. Dodatno, velika tumorska potrošnja glukoze i prisustvo metastaza u jetri mogu doprineti razvoju hipoglikemije. (2) Dodge Potterov sindrom se odnosi na hipoinsulinemijsku hipoglikemiju usled ektopične sekrecije prohormona IGF2 (proIGF2) od strane solitarnog fibroznog tumora (SFT). SFT su najčešće pleuralne lokalizacije, obično se viđaju između šeste i osme decenije i u 10-20\% su maligni. U pregledu objavljenih slučajeva nađeno je čak $56.1 \%$ malignih među torakalnim SFT koji se prezentuju hipoglikemijom. Obično je reč o velikim tumorima koji se vizuelizuju pomoću CT ili NMR. Treba imati na umu da IGF2 povećava potrošnju glukoze u perifernim tkivima, zbog čega SFT koji luči IGF2 može biti lažno negativan na FDG PET. U slučaju sumnje na Dodge Potterov sindrom potrebno je u trenutku hipoglikemije ispod $2.5 \mathrm{mmol} / \mathrm{L}$, pored suprimovane vrednosti insulina i c peptida, potvrditi visok nivo proIGF2, odnosno visok IGF2/IGF1 odnos kao surogat sekrecije prohormona IGF2. Ciljevi lečenja su da se smanji tumorska masa i da se redukuju progresija, učestalost i ozbiljnost hipoglikemija. Terapija izbora je tumorska resekcija. Hemoterapija i radioterapija se mogu primeniti adjuvantno ili kod neresektabilnih tumora, sa delimičnim uspehom. Embolizacija se nije pokazala kao uspešna. U tretmanu hipoglikemija koriste se glukagon, hormon rasta $(\mathrm{GH})$ i glukokortikoidi. (3)

\section{Prikaz slučaja}

Pacijent, star 86 godina, u novembru 2018. hospitalizovan je na našem odeljenju zbog ispitivanja hipoglikemija. Tokom prethodnog meseca je u razmaku od 3 dana imao dve krize svesti kojima je prethodila simpatička simptomatologija. Oba puta je služba hitne pomoći verifikovala hipoglikemije $1.9 \mathrm{mmol} / \mathrm{L} \mathrm{i} 1.2 \mathrm{mmol} / \mathrm{L}$ i ordinirala rastvor glukoze, na datu terapiju je došlo do potpunog oporavka. Anamnestički se saznaje da je pacijent povremeno i ranije imao vegetativnu simptomatologiju bez pratećeg poremećaja stanja svesti, ali i da je porodica primetila da je povremeno konfuzan ili uznemiren. Tokom marta 2018. je na RTG grudnog koša, učinjenom zbog produžene respiratorne infekcije, opisana mekotkivna senka koja je zatim verifikovana MSCT-om, gde je opisan tumor promera $103 \mathrm{~mm}$ u donjem desnom plućnom režnju. Iz priložene medicinske dokumentacije se vidi da je 1998. iz desnog plućnog krila operativno uklonjena tumorska promena, makroskopski ožiljnog karaktera, veličine mandarine. Histopatološki nalaz nedostaje. U ličnoj anamnezi pacijent leči hipertenzi- 
ju, apsolutnu aritmiju, benignu hiperplaziju prostate, zna za kardiomiopatiju, hronični bronchitis, anemiju i kalkulozu bubrega sa hidronefrozom, operisao je varikocelu. Pri prijemu auskultatorno postoji difuzno oslabljen disajni šum uz nečujno disanje desno bazalno. Srčana radnja je aritmična, čuje se blag sistolni šum na vrhu. Obostrano su prisutni testasti edemi potkolenica. Ostali objektivni nalaz je u referentnim granicama. U laboratorijskim nalazima se izdvaja normocitna anemija, umereno povišen CRP sa limfopenijom, hipoalbuminemija i kalemija 3.3. Nalazom urednih baznih vrednosti kortizola i ACTH je isključen hipokorticizam, tiroidni status je uredan. Ehotomografski vizuelizovane cistične promene i nekoliko hiperehogenih promena otvorene etiologije u jetri. Na MR abdomena je opisana, u prikazanim presecima pluća desno, tumorska promena $13 \times 13 \mathrm{~cm}$, obostrano pleuralni izlivi, u VII segmentu jetre cista $10 \mathrm{~mm}, \mathrm{u}$ IV segmentu dve manje ciste i nekoliko hemangioma. U desnom bubregu i u lumenu mokraćne bešike po jedan kalkulus. Na oktreoskenu u projekciji desnog hemitoraksa difuzno umereno-pojačano vezivanje sa izdvajanjem više sitnih solitarnih zona umereno-pojačane akumulacije, kao i više hladnih zona u jetri ivično. Konsultovan je grudni hirurg koji je mišljenja da se radi o recidivu solitarnog fibroznog tumora. Zbog pogoršanja hronične opstruktivne bolesti pluća je kratkotrajno ordinirana parenteralna kortikosteroidna terapija. Tokom hospitalizacije se u više navrata javljaju spontane epizode hipoglikemije, praćene dominantno simptomima neuroglikopenije. Nije bilo potrebe za testom gladi. U ovim epizodama je verifikovana vrednost glikemije ispod $2,5 \mathrm{mmol} / \mathrm{L}$ i učinjeno endokrinološko testiranje. Beleže se suprimovane vrednosti insulina i C peptida. U glukagonskom testu dolazi do adekvatnog porasta glikemije unutar 30 minuta, bez stimulacije sekrecije insulina. Nivo GH je $0.45 \mathrm{mIU} / \mathrm{L}$. Vrednost IGF1 $46.9 \mathrm{ng} / \mathrm{mL}$ je suprimovana (na osnovu tablice referentnih vrednosti za godine starosti), nivo IGF2 je snižen $357 \mathrm{ng} / \mathrm{ml}$ (referentni opseg 429-755 ng/L), uz povišen odnos IGF2/IGF1 7:1. Postavljena je dijagnoza "non-islet cell hipoglikemije" u sklopu Dodge Potter sindroma. Pacijent nije bio motivisan za predloženo operativno lečenje. Na terapiji Pronisonom nije bilo hipoglikemija do kraja hospitalizacije. Zbog brojnih komorbiditeta i potencijalnih neželjenih efekata odustalo se od uvođenja hormona rasta i pacijent je otpušten na glukokortikoidnoj terapiji.

\section{Diskusija}

Dodge Potter je redak paraneoplastični sindrom i predstavlja pojavu rekurentnih spontanih hipoinsulinemijskih hipoglikemija usled ektopične tumorske sekrecije pro IGF2 iz solitarnog fibroznog tumora. (3)

Hipoglikemije se tipično javljaju u fazi gladovanja između obroka, a kod starijih se često prezentuju samo simptomima neuroglikopenije uz blage ili odsutne adrenergičke simptome, zbog čega mogu biti otežano dijagnostikovane. Dijagnoza pleuralnog tumora može godinama prethoditi pojavi hipoglikemija. (3) 
SFT se uspešno vizuelizuju radiografski, CT-om ili NMR-om. Moguć je lažno negativan nalaz na FDG-PET skenu, zahvaljujući IGF2 - posredovanoj povećanoj potrošnji glukoze u perifernim tkivima. Iako je pronađena imunohistohemijska pozitivnost IGF2 mRNA kod čak $80 \%$ SFT, proteinska sekrecija nije prisutna kod svih ovih tumora. Postoji korelacija veličine tumora sa sekrecijom IGF2 - tumori manji od $5 \mathrm{~cm}$ su uobičajeno negativni na IGF2 mRNA, dok je veličina preko $9 \mathrm{~cm}$ dobar prediktor sekrecije. Ipak, imunohistohemijska pozitivnost na protein IGF2 nije uvek praćena razvojem kliničke slike hipoglikemija. SFT često eksprimiraju somatostatinske receptore. Slično kao i kod našeg pacijenta, u objavljenim slučajevima tumorske hipoglikemije obično je reč o velikim tumorima, većim od $10 \mathrm{~cm}$. Recidiv nakon resekcije SFT sreće se u oko $10 \%$ slučajeva i recidivantnost nije ekskluzivna za maligne tumore. Malignitet je češći kod tumora većih od $10 \mathrm{~cm} .(3,4)$

Posttranslaciona obrada pre-pro-IGF2 u tumorskim ćelijama je izmenjena. Produkt tumorske sekrecije je veliki molekul pro IGF2 koji ne zauzima adekvatnu tercijarnu strukturu, zahvaljujući čemu ima niži afinitet za proteinske nosače i lako prolazi u tkiva gde se vezuje za insulinske receptore, uzrokujući ulazak glukoze u ćelije. Sličnim mehanizmom može dovesti i do hipokalemije. Istovremeno, on na nivou hipofize dovodi do supresije sekrecije hormona rasta, rezultujući u niskim cirkulatornim nivoima IGF1 i proteinskih nosača IGFBP3, IGFBP5 i ALS. Western blot analizom se može dokazati normalan ili čak snižen nivo serumskog IGF2, uz prisustvo molekula IGF2 velike molekularne težine. Indirektni marker sekrecije pro-IGF2 je suprimovan nivo IGF1, odnosno visok odnos IGF2/IGF1, čija je vrednost u objavljenim slučajevima NICH obično bila preko 10, dok je ovaj odnos kod zdravih osoba 3:1. $(3,5,6)$ Kod našeg pacijenta je tokom spontane epizode hipoglikemije ovaj odnos bio 7. Objavljeni su slučajevi Dodge Potter sindroma gde je ovaj odnos takođe niži od 10, uz normalan nivo IGF2 i suprimovan IGF1. (8) Dodatno, naš pacijent je zbog pogoršanja hronične opstruktivne bolesti pluća pre određivanja nivoa IGF bio na terapiji visokim dozama glukokortikoida koji mogu uticati na GH-IGF osovinu u pravcu normalizacije nivoa hormona. Glukagonski test je preporučen kao dopunski dijagnostički metod u diferencijalnoj dijagnozi tumorske hipoglikemije. (1) Kod našeg pacijenta postoji nalaz tipičan za NICH: adekvatan porast glikemije uz suprimovan nivo insulina i C peptida. Beta-hidroksibutirat nije određivan iz tehničkih razloga.

Terapija izbora za Dodge Potter sindrom je totalna resekcija tumora. Terapijski efekti hemioterapije i radioterapije su samo delimični i ne postoje definisane preporuke i protokoli za njihovu primenu. Embolizacija je primenjivana u nekoliko slučajeva Dodge Potter sindroma, ali se nije pokazala kao efikasna i bezbedna. Kada operativno lečenje nije moguće, terapijski cilj je redukcija učestalosti i težine hipoglikemija, uz eliminaciju teških hipoglikemija koje mogu ostaviti posledice na centralni nervni sistem. Glukokortikoidi deluju direktno na metabolizam glukoze, ali tokom dužeg 
vremena deluju i na normalizaciju osovine GH-IGF. Terapija glukokortikoidima je veoma efikasna, ali su efekti dozno-zavisni i za postizanje punog efekta je potrebna višenedeljna primena Pronisona u dozama od $20 \mathrm{mg}$ i više. Druga terapijska opcija je primena hormona rasta u suprafiziološkim dozama, uz oprez zbog potencijalnih neželjenih efekata. Kombinovana terapija glukokortikoidima i hormonom rasta omogućava redukciju doza i neželjenih efekata oba leka. Iako SFT često eksprimiraju somatostatinske receptore, terapija analozima somatostatina nije efikasna i može čak pogoršati hipoglikemije. Terapija glukagonskom pompom primenjivana je u opisanim slučajevima Dodge Potter sindroma, ali su objavljeni rezultati kontradiktorni. $(8,9)$

\section{Zaključak}

Prikazan je pacijent koji je nedijabetičar i koji ima recidiv solitarnog fibroznog tumora pleure. Kod njega se detektuju hipoinsulinemijske hipoglikemije i suprimovane vrednosti hormona rasta i IGF1, uz povišen odnos IGF2 : IGF1. Dijagnoza retkog Dodge Potter sindroma postavljena je na osnovu tipične kliničke prezentacije i rezultata endokrinološkog testiranja. Zbog nemogućnosti resekcije tumora uvedena je terapija glukokortikoidima na kojoj se postiže adekvatna kontrola bolesti.

\section{Literatura}

1. Desimone ME., Weinstock RS. Non-Diabetic Hypoglycemia. [Updated 2017 Sep 23]. In: Feingold KR., Anawalt B., Boyce A., et al., editors. Endotext [Internet]. South Dartmouth (MA): MDText.com, Inc.; 2000. Available from: https:/www.ncbi.nlm.nih.gov/ books/NBK355894/

2. Rushakoff RJ., Siperstein A., Clark OH. Insulinoma and other Hypoglycemias. [Updated 2009 Jan 1]. In: Feingold KR., Anawalt B., Boyce A., et al., editors. Endotext [Internet]. South Dartmouth (MA): MDText.com, Inc.; 2000. Available from: https://www.ncbi. nlm.nih.gov/books/NBK278974/

3. Han G., Zhang Z., Shen X., et al. Doege-Potter syndrome: A review of the literature including a new case report. Medicine (Baltimore). 2017; 96(27): e7417. doi:10.1097/ MD.0000000000007417

4. Harrison-Phipps KM., Nichols FC., Schleck CD., et al. Solitary fibrous tumors of the pleura: results of surgical treatment and long-term prognosis. J Thorac Cardiovasc Surg. 2009; 138(1): 19-25. doi:10.1016/j.jtcvs.2009.01.026

5. Yevgeniya Dynkevich, Kristina I. Rother, Ian Whitford, Sana Qureshi, Sneha Galiveeti, Alessandra L. Szulc, Ann Danoff, Tracy L. Breen, Nargess Kaviani, Michael H. Shanik, Derek LeRoith, Riccardo Vigneri, Christian A. Koch, Jesse Roth. Tumors, IGF-2, and Hypoglycemia: Insights From the Clinic, the Laboratory, and the Historical Archive. Endocrine Reviews, Volume 34, Issue 6, 1 December 2013, 798-826. 
6. Fukuda I., Asai A., Nagamine T. et al. Levels of glucose-regulatory hormones in patients with non-islet cell tumor hypoglycemia: Including a review of the literature. Endocrine Journal. 2017; 64.

7. Tay CK., Teoh HL., Su S. A common problem in the elderly with an uncommon cause: hypoglycaemia secondary to the Doege-Potter syndrome. BMJ Case Rep. 2015; 2015:bcr2014207995.

8. Bodnar TW., Acevedo MJ., Pietropaolo M. Management of non-islet-cell tumor hypoglycemia: a clinical review. J Clin Endocrinol Metab. 2014; 99(3): 713-722. doi:10.1210/ jc.2013-3382

9. Tsuro K., Kojima H., Okamoto S. et al. Glucocorticoid therapy ameliorated hypoglycemia in insulin-like growth factor-II-producing solitary fibrous tumor. Intern Med. 2006; 45(8): 525-9. 